\title{
HOUSE PRICES, RENTAL COSTS, AND MORTGAGE INTEREST RATES
}

\author{
Che-Chun LIN ${ }^{1,2}$, I-Chun TSAI ${ }^{3, *}$ \\ ${ }^{1}$ Department of Quantitative Finance, National Tsing Hua University, Hsinchu, Taiwan \\ ${ }^{2}$ Anfu Institute for Financial Engineering, National Tsing Hua University, Hsinchu, Taiwan \\ ${ }^{3}$ Department of Finance, National University of Kaohsiung, Kaohsiung, Taiwan
}

Received 11 December 2020; accepted 15 April 2021

\begin{abstract}
Studies have typically adopted the price-rent ratio to determine whether housing exuberance exists and the periods of imbalance between house prices and rental costs. Using the price-rent ratio to conduct tests without considering the effects of mortgage interest rates on user costs may overestimate episodes of exuberance. This study uses data of the overall housing market and those of 10 major metropolitan statistical areas (MSAs) in the United States from 1979Q1 to 2018Q1 to evaluate whether housing exuberance exists in the markets; the results indicate that all the MSAs experienced episodes of exuberance at different times and the overall housing U.S. market was overheated from 1998Q2 to 2007Q3. By considering mortgage rates and using the user-cost-rent ratio, we further determine that short-term housing exuberance emerged in only two MSAs, Los Angeles and Miami, in 2006Q2, which was followed by immediate corrections. Thus, the research results of this study signify that only use the price-rent ratio to determine whether or not rational housing tenure choice made by traders exists is not sufficient. This study provides evidence showing that the method incorporating mortgage interest rates tends to obtain an equilibrium relationship between the rental and housing markets, indicating interest rates play an important role in housing tenure choice.
\end{abstract}

Keywords: housing tenure choice, episodes of exuberance, price-rent ratio, mortgage rate, US housing markets.

\section{Introduction}

Research on the correlations between house prices and rental costs has predominantly employed two types of methods: one is to test the stationary sequence of the price-rent ratio to verify the balance between house prices and rental costs, and the other one is to estimate the rent-price ratio to examine house price misvaluations. These two types of methods both involve directly evaluating the price-rent ratio to determine the reasonableness of house prices in relation to rental costs. However, many previous studies well documented that rent has rigidity in the short term; for example, Shimizu et al. (2010) found evidence showing rent rigidity in Japan; Genesove (2003) reported the phenomenon regarding rent rigidity in the United States, and Hoffmann and Kurz-Kim (2006) also showed the similar phenomenon in Germany. Housing rent price rigidity might be caused by rent regulation (Rapaport, 1992) or the framing effect of rental housing markets (Tsai, 2020).

If rents cannot adjust dynamically in the short term, whereas house prices change with the other fundamental factors in the housing market, only use the price-rent ratio to determine whether housing exuberance exists may overestimate the periods of imbalance between house prices and rental costs. Besides, when rent fluctuations are rigid, people's behavior of renting and buying houses will change, and house prices will also be affected. Therefore, past research has also found that the fluctuation behavior of house prices might be asymmetric. For example, André et al. (2019) provided evidence of asymmetric house prices from the US states and metropolitan areas. Chu and Tsai (2020) also proposed that the house price volatilities in Taiwan are asymmetric. Compared with the direct comparison of the price-rent ratio, exploring the equilibrium of house prices and rental costs in housing tenure choice will have more economic implications. From the perspective of housing tenure choice, this study proposes that the user-cost-rent ratio that incorporates mortgage interest rates can be tested to determine if housing markets are overheated relative to rental markets to further identify episodes of exuberance in housing markets.

Previous studies have adopted the price-rent ratio to probe housing markets (Chen, 1996; Kishor \& Morley, 2015; Hill \& Syed, 2016). In these studies, some researchers have evaluated the imbalance between house prices and rental costs by determining whether the price-rent ratio is a stationary sequence. Shi (2007) uses both a

*Corresponding author. E-mail: ictsai@nuk.edu.tw

Copyright $\odot 2021$ The Author(s). Published by Vilnius Gediminas Technical University

This is an Open Access article distributed under the terms of the Creative Commons Attribution License (https://creativecommons.org/licenses/by/4.0/), which permits unrestricted use, distribution, and reproduction in any medium, provided the original author and source are credited. 
traditional unit root test and a unit root test with consideration to structural changes to identify any bubbles emerging in the apartment market of Seoul, South Korea. Based on the research statistics of the house price and rent indices of apartments in Seoul from 1986Q1 to 2006Q3, the researcher finds no evidence of bubbles in the market. Bourassa et al. (2019) calculate the equilibrium price-rent ratio of six cities in Finland (Helsinki), Switzerland (Geneva and Zurich), and the United States (Chicago, Miami, and San Francisco) by using data between 1980Q1 and 2012Q4. The researchers identify imbalanced house prices by dividing the real price-rent ratio by the equilibrium price-rent ratio, thereby determining that housing bubbles existed in Helsinki in the 1970s and the 1980s and in Miami in the late 2000s. However, no bubbles were found in the other cities.

Recent studies have adopted innovative quantitative methods to obtain dynamic indicators with which to evaluate whether the price-rent ratio is out of balance. Pavlidis et al. (2016) explore housing market exuberance in 22 countries between 1975Q1 and 2013Q2 and identify predictors for the exuberance. By adopting the unit root test method proposed by Phillips et al. (2011, 2015), the researchers conduct tests on real house prices, the price-income ratio, and the price-rent ratio and observe that housing exuberance emerged between mid-1990s and early 2000s in the United States, Ireland, Norway, and Switzerland and that the number of countries exhibiting housing exuberance increased to 18 in the early to mid-2000s. However, housing exuberance disappeared in 2006 and 2007, before the outbreak of the U.S. subprime mortgage crisis.

Many researchers have analogized housing markets to stock markets and used the rent-price ratio to identify house price misvaluations. Campbell and Shiller (1988, 1998) propose that if a stock price rises much faster than its dividend, this will jeopardize its future rising momentum. Leamer (2002) contends that the rent-price ratio of housing markets can be intuitively compared to the dividend-price ratio of stock markets. Accordingly, many studies have used the rent-price ratio to explore potential house price growth. Campbell et al. (2009) use the dynamic Gordon growth model to analyze factors affecting the rent-price ratio by compiling the statistical data of the 23 metropolises in the United States between 1975 and 2007. The results indicate a difference between the real rent-price ratios and the estimated reasonable values, which confirms the misvaluation of house prices against rental costs, and that the difference is enlarged after 2000. Engsted and Pedersen (2015) calculate the rent-price ratio of 18 Organisation for Economic Co-operation and Development countries between 1970Q1 and 2011Q4, applying the stock market model proposed by Campbell and Shiller (1988) to convert the rent-price ratio into a log-linear form and discuss the ability of the rent-price ratio to predict return rates and rent growth rates in the future. The researchers confirm that house prices have been overpriced and such misvaluation is related to infla- tion rates-people in the housing markets are under the money illusion.

The aforementioned studies investigate the rent-price ratio by categorizing real property as a capital good, and the results all prove imbalance in housing markets or house price misvaluations. However, Feng and Wu (2015) use the rent-price ratio to examine housing bubbles in China. By referring to the theory developed by Poterba $(1984,1991)$, the researchers posit the rent-price ratio to be equivalent to the difference between the user cost and the expected growth rate of house prices; when the rentprice ratio is less than such difference, it means a housing market is in a bubble and has deviated from its fundamentals. After evaluating data from 35 major cities between 2003 and 2011, the researchers find no evidence of housing bubbles in those cities.

The perspective proposed by Feng and Wu (2015) is consistent with the theory of housing tenure choice. Although Campbell et al. (2009) and Engsted and Pedersen (2015) regard real property as a capital good, previous studies on the tenure choice theory (Kent, 1984; Bourassa \& Yin, 2008; Alkay, 2015; Tabner, 2016) or on the behaviors of tenants in real estate markets (Fonseca et al., 2018; Nowak et al., 2020) have regarded real property as a consumer good. The tenure choice theory holds that people have two residential choices: either renting or buying a house; thus, people can choose one of these two alternatives to satisfy their housing need. While tenants incur rental costs, those who choose to buy a house incur user costs associated with ownership of real property. In an equilibrium scenario, the costs of the two choices should be identical; otherwise, people would be inclined to favor one choice, resulting in cost correction of the other choice.

A recent study by Pavlidis et al. (2016) constructs dynamic indicators to evaluate whether the price-rent ratio is out of balance. These indicators assume that rent is a fundamental factor that effectively measures changes in house prices. Although rent regulation can lead to longerterm residential stability, it may also cause an imbalance in the rental housing market. Therefore, whether to deregulate rent controls has always been a controversial issue (Been et al., 2019). This article used data from the 10 major metropolitan statistical areas (MSAs) in the United States. Many of these areas are subject to rent control, so underestimation and rigidity of rent may exist in these areas. In this case, just using the price-rent ratio may result in the results showing a persistently high house price and will not be able to accurately estimate the overheating phenomenon of the housing market. Hence, the present study refers to the tenure choice theory and revises the method for testing a housing market for exuberance, using the ratio of user costs to rental costs to determine if housing markets are more exuberant than rental markets. The results of this study can be used to better determine whether an equilibrium exists between housing markets and rental markets and explain whether nonfundamental housing bubbles contribute to the imbalance between house prices rental costs. 


\section{Theoretical framework}

Considering real property is a key asset for many people, numerous researchers have developed theories with which to analyze reasonable house prices and housing market equilibrium. Theoretical models used to determine reasonable house prices all involve explaining the relationship between house prices and rental costs and can be categorized into three types depending on the role of rental costs. The first type is the supply and demand equilibrium model for housing market that is premised on the contention that house prices are determined by the supply and demand functions of a housing market; rental costs can affect demand for buying houses (Reichert, 1990), and thus fundamental factors, including rental costs, can affect the equilibrium house price. The second type is the present value model of assets (Hamilton, 1986; Campbell \& Shiller, 1988), which determine the present value of assets by discounting expected asset income (i.e., rental proceeds or dividends) back to present value. Although this type of model has been primarily applied to stocks, Brunnermeier and Julliard (2008) and Campbell et al. (2009) further extend the concept to real property. Finally, the user cost model or the tenure choice model (Poterba, 1984) is premised on the contention that house prices and rental costs maintain an equilibrium relationship under a noarbitrage condition; therefore, rental costs can be used to estimate reasonable house prices.

The first model (i.e., the supply and demand equilibrium model for housing markets) considers real property to be a regular good from an economic perspective. The second model (i.e., the present value model of assets) analogizes real property to stocks from a financial perspective. The third model (i.e., the tenure choice model) is a unique theory of real property markets that explores the decision making of people to either rent or buy a house to satisfy their housing need.

The relationship between rental costs and house prices in the tenure choice model is concisely explained as follows.

People can satisfy their housing need by either renting or buying a house; the two choices are only different in their costs. Those who choose to rent a house bear rental costs as their housing costs, whereas those who choose to buy a house incur both the price of the house itself and all the tangible and intangible costs related to the house during ownership. Therefore, the user cost theory assumes that housing markets and rental markets serve as a substitute to each other if no other market limits (e.g., loan limits) exist; that is, when a no-arbitrage equilibrium is established, the cost for a tenant to rent a house for one term should be equivalent to the user cost for one to own a house for one term, which can be expressed as follows:

$$
R_{t}=P_{t} \times U C_{t},
$$

where: $R_{t}$ represents the real rental costs in the $t^{\text {th }}$ term (housing costs for one term); $P_{t}$ represents the real house prices in the $t^{\text {th }}$ term; $U C_{t}$ is the real unit user costs in the $t^{\text {th }}$ term. Attendant to the ownership of houses, user costs include the sum of mortgage interest, taxes (e.g., house tax and land value tax), and maintenance due to depreciation minus the expected capital gains on house ownership. Himmelberg et al. (2005) precisely describe the six essential factors of real user costs of house owners as follows:

$$
U C_{t}=r_{t}^{r f}+\omega_{t}-\tau_{Y, t}\left(r_{t}^{r m}+\omega_{t}\right)+\delta+\gamma-g_{t+1},
$$

where: $r_{t}^{r f}$ is the real risk-free interest rate; $\omega_{t}$ is the tax of a house owner; $\tau_{Y, t}$ is the income tax rate; $r_{t}^{r m}$ is the mortgage interest rate; $\tau_{Y, t}\left(r_{t}^{r m}+\omega_{t}\right)$ is the amount of tax deduction of a house owner; $\delta$ is the depreciation rate of a house; $\gamma$ is the risk premium to compensate the risk of house ownership; $g_{t+1}$ is the expected rate of increase of real house prices in the next term. The variables $\tau_{Y, t}$ and $\omega_{t}$ in (2) do not change in a short period of time; therefore, many researchers assume them as constants (Zorn, 1988; Bourassa \& Yin, 2008).

Bourassa and Yin (2008) and Bourassa et al. (2010) consider $\mathrm{v}$ as the loan-value ratio to detail user costs in the United States, and user costs can be different due to this ratio. On the basis of these two studies, the authors of the present study further revise Equation (2):

$U C_{t}=\left(1-\tau_{Y}\right)(1-v) r_{t}^{r f}+\left(1-\tau_{Y}\right)\left(v r_{t}^{r m}+\omega\right)+\delta+\gamma-g_{t+1}$.

When an equilibrium relationship exists between renting and housing markets, the cost of one term of house ownership should not exceed one term of rental costs. If the user costs of house ownership increase but rental costs fail to rise simultaneously, people will prefer renting over buying a house. When people are inclined to rent a house, house prices will fall due to a correction and rental costs will rise, thereby resulting in rental costs being equivalent to the user costs of house ownership in a single term. Therefore, we can combine Equations (1) and (3) to obtain the equilibrium condition below:

$$
\begin{aligned}
& P_{-}^{-} R=U C ; \\
& U C_{t}=F\left(\tau_{Y}, v, r_{t}^{r f}, r_{t}^{r m}, \omega, \delta, \gamma, g_{t+1}\right) .
\end{aligned}
$$

As expressed in Equation (4a), the price-rent ratio should be equivalent to the reciprocal of the user costs. In Equation (4b), the user costs are affected by multiple variables, but $\tau_{Y}, v, \omega, \delta$ and $\gamma$ are constants. Moreover, because the mortgage interest rate $r_{t}^{r m}$ is equivalent to the sum of risk-free interest rate and risk premium $\left(r_{t}^{r f}+\gamma\right)$, Equation (4b) is revised as follows:

$$
U C_{t}=F_{0}+F_{t}\left(r_{t}^{r m}, g_{t+1}\right) \text {. }
$$

As expressed in Equation (5), the functions of the user costs are affected by the constant term $\left(F_{0}\right)$, the mortgage interest rate $\left(r_{t}^{r m}\right)$, and the expected increase rate of house prices in the next term $\left(g_{t+1}\right)$.

Whether price-rent ratios form a divergent sequence has been used by previous studies to determine the existence of bubbles (Mikhed \& Zemčík, 2009; Xie \& Liu, 2004) and exuberance (Pavlidis et al., 2016; Tsai \& Chiang, 
2019) in housing markets. These studies assume $1 / U C_{t}$ to be a stationary sequence. Since these studies do not consider the influence of the mortgage interest rate $r_{t}^{r m}$ on the user costs, we can also assume the mortgage interest rate $r_{t}^{r m}$ is a constant and revises Equation (5) as follows:

$$
U C_{t}=F_{0}+F_{t}\left(g_{t+1}\right) \text {. }
$$

According to Equation (6), when $P_{t} / R_{t}$ is divergent, it means that the rate of increase of house prices causes the divergence of the price-rent ratio. Specifically, this study investigates if the mean reversion exists by examining whether $\frac{P_{t-1}\left(1+g_{t}\right)}{R_{t}}$ approaches a constant. If the mean reversion does not exist, it means bubbles have emerged in housing markets relative to rental markets.

However, the mortgage interest rate $r_{t}^{r m}$ can fluctuate over time, and such fluctuation may be nonstationary. We revise Equation (5) and let $g_{t+1}=0$. Under this hypothesis, house price bubbles do not exist, and the equilibrium condition between housing markets and rental markets is expressed as follows:

$$
P_{t} / R_{t}=1 / U C_{t}\left(r_{t}^{r m}\right)
$$

That is, $\left(P_{t} \times r_{t}^{r m}\right) / R_{t}$ is a stationary sequence.

Pavlidis et al. (2016) conduct tests by using the pricerent ratio and use the test results and threshold values to estimate the episodes of exuberance in housing markets of sample countries. The analysis method proposed by Pavlidis et al. (2016) may have overestimated episodes of housing exuberance because they analyze the housing markets from the perspective of Equation (6); that is, the researchers do not consider the influences of the mortgage interest rate $r_{t}^{r m}$ on user costs.

According to Equation (7), which is based on the hypothesis that traders are rational when making housing tenure choice, the equilibrium relationship between housing and rental markets can be expressed as $P_{t} / R_{t}=1 / U C_{t}\left(r_{t}^{r m}\right)$. Therefore, controlling the mortgage interest rate is necessary to maintain the price-rent ratio as a stationary sequence. When $1 / r_{t}^{r m}$ is not divergent, the price-rent ratio converges towards a constant. Consequently, the present study compares the episodes of exuberance in various United States housing markets from the perspectives of Equations (6) and (7).

\section{Empirical model}

Phillips and Yu (2011) and Phillips et al. (2011) proposed a sup augmented Dickey-Fuller test (ADF) tests, namely, SADF test. Phillips et al. (2015) proposed a generalized version of a SADF (GSADF) test. Pavlidis et al. (2016) conduct SADF and GSADF tests on the price-rent ratio in an attempt to diagnose episodes of exuberance in housing markets. Viewed in light of the tenure choice theory, the analytic method proposed by Pavlidis et al. (2016) can overestimate the episodes of exuberance in housing markets. Therefore, this study also conduct SADF and GSADF tests to examine the price-rent ratio and the ratio of user costs to rental costs to identify episodes of exuberance. The test method is explained below:

Let $y_{t}$ be the price-rent ratio:

$$
\begin{aligned}
& \Delta y_{t}=a_{r_{1}, r_{2}}+\rho_{r_{1}, r_{2}} y_{t-1}+\sum_{i=1}^{q} \phi_{r_{1}, r_{2}}^{i} \Delta y_{t-i}+\varepsilon_{t} ; \\
& \quad \varepsilon_{t} \sim N\left(0, \sigma_{r_{1}, r_{2}}^{2}\right),
\end{aligned}
$$

where: $r_{1}$ and $r_{2}$ denote the starting and ending points of a subsample period; $q$ is the maximum number of lags included in the specification; $a_{r_{1}, r_{2}}, \rho_{r_{1}, r_{2}}$, and $\phi_{r_{1}, r_{2}}^{i}$ are regression coefficients; $\varepsilon_{t}$ is the error term. Equation (8) has a null hypothesis of $\rho_{r_{1}, r_{2}}=0$ and is a right-tailed test; therefore, the alternative hypothesis is $\rho_{r_{1}, r_{2}}>0$. When the test statistic exceeds the corresponding critical value, the unit root hypothesis is rejected, indicating that the explosive behavior exists. Testing statistics will be:

$$
A D F_{r_{1}}^{r_{2}}=\frac{\hat{\rho}_{r_{1}, r_{2}}}{\text { s.e. }\left(\hat{\rho}_{r_{1}, r_{2}}\right)} \text {. }
$$

Let $r_{1}=0$ and $r_{2}=1$, the standard ADF test statistic can be obtained, that is $A D F_{0}^{1}$. The limit distribution of $A D F_{0}^{1}$ is given by:

$$
\frac{\int_{0}^{1} W d W}{\left(\int_{0}^{1} W^{2}\right)^{\frac{1}{2}}},
$$

where $W$ is a Wiener process.

Phillips and Yu (2011) propose the SADF test, which can be expressed as follows:

$$
\operatorname{SADF}\left(r_{0}\right)=\sup _{r_{2} \in\left[r_{0}, 1\right]} A D F_{0}^{r_{2}} .
$$

The GSADF tests proposed by Phillips et al. (2015) can be used to dynamically and endogenously determine the test period and can be expressed as follows:

$$
\operatorname{GSADF}\left(r_{0}\right)=\sup _{r_{2} \in\left[r_{0}, 1\right], r_{1} \in\left[0, r_{2}-r_{0}\right]} A D F_{r_{1}}^{r_{2}},
$$

where the window size of each estimation is $r_{\text {window }}=$ $r_{2}-r_{1}$. The null hypothesis of the GSADF test is $\rho_{r_{1}, r_{2}}=0$; $\rho_{r_{1}, r_{2}}$ being significantly larger than zero indicates the existence of housing exuberance.

\section{Estimated results}

This study uses the house prices and rental costs of the overall housing market and those of 10 largest MSAs in the United States from 1979Q1 to 2018Q1 to verify the study's inferences. The data are collected from the Zillow Transaction and Assessment Dataset. ${ }^{1}$

1 Data provided by Zillow through the Zillow Transaction and Assessment Dataset (ZTRAX). More information on accessing the data can be found at http://www.zillow.com/ztrax. The results and opinions are those of the author(s) and do not reflect the position of Zillow Group. 
Table 1 presents the simple statistical and unit root test of house prices, and Table 2 presents the simple statistical and unit root test of rental costs. Regarding the average house price, Los Angeles ranks the highest among the $10 \mathrm{MSAs}$, followed by New York. Regarding average rental costs, Los Angeles also ranks the highest, followed by New York. Although the two are ranked the same in both house price and rental costs, the house price gap between Los Angeles and New York is larger than the rent gap between them. Figure 1 depicts the trends in the house prices, and Figure 2 presents the trends in the rental costs. The house prices and rental costs in Los Angeles are significantly higher than those in other MSAs, and fluctuations in the house prices are substantial. By comparing Figures 1 and 2, it is evident that the fluctuations in house prices in all MSAs other than Dallas and Houston are more significant than the fluctuations in rental costs.
Tables 1 and 2 present the results of the test of the sequence characteristics of house prices and rental costs. In these table, this study uses the traditional unit root test to determine whether the data is stationary. The empirical results indicate that all the house price and rental cost data are nonstationary. Some researchers (e.g., Mikhed \& Zemćík, 2009) have argued that when house prices and rental costs are nonstationary but the price-rent ratios are stationary, the house prices and rental costs are integrated, meaning that house prices and rental costs are under a common trend of fluctuations and the trend of house prices does not deviate from that of rental costs. Therefore, whether the sequence of the price-rent ratio is divergent can be used to determine whether housing bubbles or exuberance exists (Pavlidis et al., 2016; Tsai \& Chiang, 2019).

Table 1. The simple statistical and unit root test of house prices

\begin{tabular}{|c|c|c|c|c|}
\hline & United States & New York & Los Angeles & Chicago \\
\hline Mean & 121171.5392 & 238082.8417 & 293117.7942 & 146721.3301 \\
\hline Median & 112394 & 177693 & 208302 & 144980 \\
\hline Maximum & 213146 & 450801 & 645199 & 253912 \\
\hline Minimum & 47671.4202 & 51206.5657 & 71924.0710 & 60641.9783 \\
\hline Std. Dev. & 48056.0086 & 123871.6347 & 173466.2524 & 57090.2302 \\
\hline \multicolumn{5}{|c|}{ Phillips-Perron unit root test } \\
\hline In level & $\begin{array}{c}2.2270 \\
(0.9939)\end{array}$ & $\begin{array}{c}1.4568 \\
(0.9638)\end{array}$ & $\begin{array}{c}1.4711 \\
(0.9648)\end{array}$ & $\begin{array}{c}1.1458 \\
(0.9347)\end{array}$ \\
\hline In differenced & $\begin{array}{c}-1.9559^{* *} \\
(0.0485)\end{array}$ & $\begin{array}{l}-1.7684 \\
(0.0732)\end{array}$ & $\begin{array}{c}-2.5831^{\star * *} \\
(0.0099)\end{array}$ & $\begin{array}{c}-2.9537^{\star * *} \\
(0.0033)\end{array}$ \\
\hline & Dallas & Philadelphia & Houston & Washington, D. C. \\
\hline Mean & 129712.4673 & 135945.6680 & 119495.2205 & 221000.4111 \\
\hline Median & 124990 & 112803 & 113601 & 159759 \\
\hline Maximum & 227395 & 237432 & 196155 & 440193 \\
\hline Minimum & 72885.0582 & 41605.8927 & 77624.3706 & 65414.8837 \\
\hline Std. Dev. & 26641.5129 & 60317.7647 & 27852.1268 & 116102.8279 \\
\hline \multicolumn{5}{|c|}{ Phillips-Perron unit root test } \\
\hline In level & $\begin{array}{c}2.9279 \\
(0.9992)\end{array}$ & $\begin{array}{c}1.6472 \\
(0.9757) \\
\end{array}$ & $\begin{array}{c}2.6576 \\
(0.9981) \\
\end{array}$ & $\begin{array}{c}1.2056 \\
(0.9414)\end{array}$ \\
\hline In differenced & $\begin{array}{c}-2.2287^{\star *} \\
(0.0253)\end{array}$ & $\begin{array}{c}-2.2980^{\star *} \\
(0.0213)\end{array}$ & \multirow[t]{2}{*}{$\begin{array}{c}-7.0141^{* * *} \\
(0.0000)\end{array}$} & $\begin{array}{c}-2.6495^{\star * *} \\
(0.0082)\end{array}$ \\
\hline & & & & Boston \\
\hline Mean & 1320 & & & 226853.8248 \\
\hline Median & & & & 181718 \\
\hline Maximum & & & & 450235 \\
\hline Minimum & 4884 & & & 46171.5201 \\
\hline Std. Dev. & 7026 & & & 116729.0380 \\
\hline & & Phillips-P & & \\
\hline In level & $\begin{array}{r}0 . \\
(0.8 \\
\end{array}$ & & & $\begin{array}{c}2.2911 \\
(0.9948)\end{array}$ \\
\hline In differenced & $\begin{array}{r}-2.7 \\
(0 .\end{array}$ & & & $\begin{array}{l}-1.9344 \\
(0.0510)\end{array}$ \\
\hline
\end{tabular}

Notes: The estimated Phillips-Perron unit root test model is without intercept and trend. The entry in parenthesis stands for the $p$-value. The symbols ${ }^{* *}$ and ${ }^{* *}$ denote significance at the $1 \%$ and $5 \%$ level, respectively. 
Table 2. The simple statistical and unit root test of rental costs

\begin{tabular}{|c|c|c|c|c|}
\hline & United States & New York & Los Angeles & Chicago \\
\hline Mean & 879.8869 & 1258.542 & 1487.109 & 1041.863 \\
\hline Median & 850.1871 & 1086.342 & 1331.126 & 979.3636 \\
\hline Maximum & 1447 & 2417 & 2753 & 1654 \\
\hline Minimum & 337.1368 & 396.6895 & 488.7835 & 394.1054 \\
\hline Std. Dev. & 321.4544 & 606.0774 & 610.4334 & 399.1683 \\
\hline \multicolumn{5}{|c|}{ Phillips-Perron unit root test } \\
\hline In level & $\begin{array}{c}9.2591 \\
(1.0000) \\
\end{array}$ & $\begin{array}{c}9.4900 \\
(1.0000)\end{array}$ & $\begin{array}{c}7.5587 \\
(1.0000) \\
\end{array}$ & $\begin{array}{c}5.9019 \\
(1.0000) \\
\end{array}$ \\
\hline \multirow[t]{2}{*}{ In differenced } & $\begin{array}{c}2.4166^{\star *} \\
(0.0156)\end{array}$ & $\begin{array}{c}-4.6350^{* * *} \\
(0.0000)\end{array}$ & $\begin{array}{c}-2.4404^{\star *} \\
(0.0147)\end{array}$ & $\begin{array}{c}-4.3568^{\star * *} \\
(0.0000)\end{array}$ \\
\hline & Dallas & Philadelphia & Houston & Washington, D. C. \\
\hline Mean & 888.3211 & 931.0209 & 921.7257 & 1121.666 \\
\hline Median & 822.3249 & 797.4502 & 869.2312 & 854.8395 \\
\hline Maximum & 1606 & 1582 & 1584 & 2148 \\
\hline Minimum & 347.0251 & 328.5130 & 366.8199 & 305.6321 \\
\hline Std. Dev. & 366.6376 & 410.2022 & 366.9377 & 611.3768 \\
\hline \multicolumn{5}{|c|}{ Phillips-Perron unit root test } \\
\hline In level & $\begin{array}{l}13.1472 \\
(1.0000) \\
\end{array}$ & $\begin{array}{c}5.5276 \\
(1.0000) \\
\end{array}$ & $\begin{array}{c}6.9945 \\
(1.0000) \\
\end{array}$ & $\begin{array}{c}4.9975 \\
(1.0000) \\
\end{array}$ \\
\hline \multirow[t]{2}{*}{ In differenced } & $\begin{array}{c}2.2300^{\star \star} \\
(0.0253)\end{array}$ & $\begin{array}{c}-3.5957^{\star * *} \\
(0.0004)\end{array}$ & $\begin{array}{c}-3.1477^{\star * *} \\
(0.0018)\end{array}$ & $\begin{array}{c}-4.0743^{\star * *} \\
(0.0001)\end{array}$ \\
\hline & \multicolumn{2}{|l|}{ Miami } & Atlanta & Boston \\
\hline Mean & \multicolumn{2}{|l|}{1029.5547} & 806.2273 & 1231.2336 \\
\hline Median & \multicolumn{2}{|l|}{891.5447} & 768.2396 & 1045.6564 \\
\hline Maximum & \multicolumn{2}{|l|}{1887} & 1397 & 2379 \\
\hline Minimum & \multicolumn{2}{|l|}{347.8036} & 260.2313 & 377.3374 \\
\hline Std. Dev. & \multicolumn{2}{|l|}{464.9976} & 329.0358 & 554.2467 \\
\hline \multicolumn{5}{|c|}{ Phillips-Perron unit root test } \\
\hline In level & \multicolumn{2}{|l|}{$\begin{array}{c}6.4465 \\
(1.0000)\end{array}$} & $\begin{array}{c}6.1666 \\
(1.0000)\end{array}$ & $\begin{array}{c}8.4219 \\
(1.0000) \\
\end{array}$ \\
\hline In differenced & $\begin{array}{c}-2.4737^{\star \star} \\
(0.0134)\end{array}$ & & $\begin{array}{c}-2.8904^{* * *} \\
(0.0040)\end{array}$ & $\begin{array}{c}-2.6216^{* * *} \\
(0.0089)\end{array}$ \\
\hline
\end{tabular}

Notes: The estimated Phillips-Perron unit root test model is without intercept and trend. The entry in parenthesis stands for the $p$-value. The symbols ${ }^{* *}$ and ${ }^{* *}$ denote significance at the $1 \%$ and $5 \%$ level, respectively.

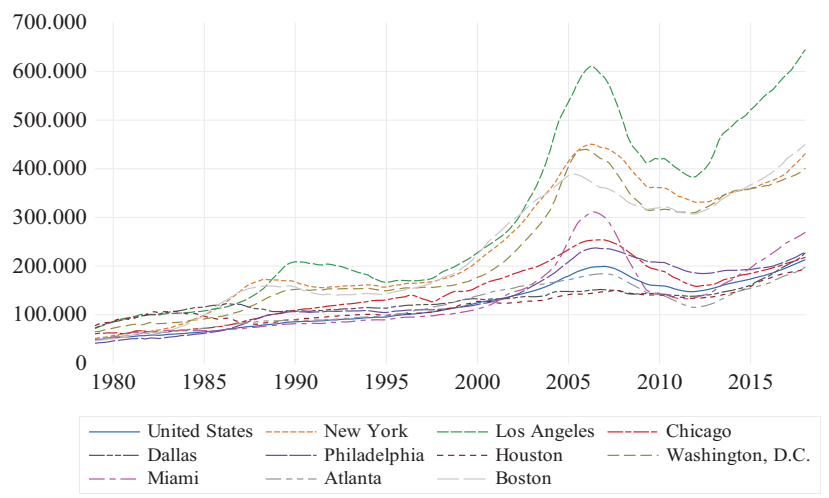

Figure 1. House prices

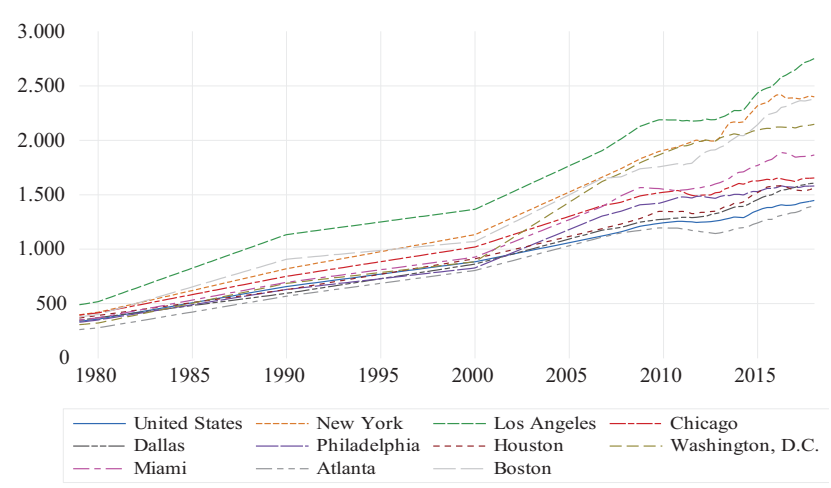

Figure 2. Rents 
Table 3 lists the estimation results yielded by the unit root test method (SADF and GSADF tests) proposed by Phillips and Yu (2011) and Phillips et al. (2015) using the price-rent ratio. The estimation results show the existence of considerable exuberance in the overall housing market. The estimation results of the SADF test show that the episode of exuberance with the maximum SADP statistic emerged from the beginning of the sampling period to March 2005, which represents that the overall housing market in the United States was overheated by at least March 2005. The GSADF test in Table 3 reveals the periods when endogenous structural changes occur $\left(r_{1}\right.$ and $\left.r_{2}\right)$, which depicts the business climate changes in the markets and particularly uncovers the periods when market exuberance appears. According to the estimation results of the GSADF test, the episode of overall housing exuberance in the United States was likely from 1984Q1 to 2005Q3. This episode of housing exuberance had been maintained for a long time, which raises the question of why the market (especially the housing supply side) has not been corrected for such a long time. Another thing worth noting is that although the US housing loan market's correction appeared in 2007 and triggered the housing bubble to burst, the overheating phenomenon of the US housing market disappeared as early as 2005 Q3.

Both the estimation results of the SADF or the GSADF test, presented in Table 3, indicate significant housing exuberance in all the MSAs. Moreover, the episode of housing exuberance in Miami was between 1987Q2 and 2005Q3, which almost aligns with the episode of housing exuberance in the overall U.S. market. The results of this part of the study are consistent with previous studies. In the literature that also used the SADF or the GSADF test to test the price-rent ratio, Engsted et al. (2016) and Pavlidis et al. (2016) both proposed evidence showing many countries existed the episode of housing exuberance and Tsai and Chiang (2019) also found the evidence of the housing price bubble in Beijing, China.

Phillips et al. (2015) propose that the dynamic backward SADF statistic (BSADF) tests involve using rolling windows to make predictions. According to the selection standard for window size suggested by Phillips et al. (2015), the present study determines the size of window to be 24 terms. Figures 3 and 4 depict the statistics of the dynamic BSADF tests, and SCV represents the critical values of the statistics (at the significance level of 5\%). If the statistics of the BSADF test exceed SCV, it indicates significant existence of housing exuberance. The GASDF test presented in Table 3 presents only the interval in which the maximum statistics occur in the sampling period (i.e., the most likely period of housing exuberance). By contrast, the statistics of the BSADF reveal multiple episodes of exuberance, enabling the dynamic detection of episodes of exuberance at all time points.
Table 3. Results of SADF and GSADF tests (price-rent ratio)

\begin{tabular}{|c|c|c|}
\hline MSA & Statistic & Period \\
\hline \multicolumn{3}{|c|}{ United States } \\
\hline SADF Statistic & $6.1672^{\star * \star}$ & sample through 2005Q3 \\
\hline GSADF Statistic & $10.8927^{\star * *}$ & $\begin{array}{l}\text { sample from 1984Q1 to } \\
\text { 2005Q3 }\end{array}$ \\
\hline \multicolumn{3}{|c|}{ New York } \\
\hline SADF Statistic & $6.3123^{\star * *}$ & sample through 1987Q2 \\
\hline GSADF Statistic & $8.5000^{* * *}$ & $\begin{array}{l}\text { sample from 1995Q2 to } \\
\text { 2004Q4 }\end{array}$ \\
\hline \multicolumn{3}{|c|}{ Los Angeles } \\
\hline SADF Statistic & $7.6292^{\star * *}$ & sample through $2004 \mathrm{Q} 3$ \\
\hline GSADF Statistic & $14.7608^{\star * *}$ & $\begin{array}{l}\text { sample from 1995Q1 to } \\
\text { 2004Q3 }\end{array}$ \\
\hline \multicolumn{3}{|c|}{ Chicago } \\
\hline SADF Statistic & $1.4438^{* *}$ & sample through 2005Q4 \\
\hline GSADF Statistic & $3.1032^{\star * *}$ & $\begin{array}{l}\text { sample from 2003Q3 to } \\
\text { 2009Q3 }\end{array}$ \\
\hline \multicolumn{3}{|c|}{ Dallas } \\
\hline SADF Statistic & $1.6415^{\star \star}$ & sample through 1990Q4 \\
\hline GSADF Statistic & $7.3636^{* * *}$ & $\begin{array}{l}\text { sample from 2011Q2 to } \\
\text { 2018Q1 }\end{array}$ \\
\hline \multicolumn{3}{|c|}{ Philadelphia } \\
\hline SADF Statistic & $3.1948^{* * *}$ & sample through 1988Q2 \\
\hline GSADF Statistic & $8.3926^{* * *}$ & $\begin{array}{l}\text { sample from 1996Q1 to } \\
\text { 2005Q3 }\end{array}$ \\
\hline \multicolumn{3}{|c|}{ Houston } \\
\hline SADF Statistic & $1.7301^{\star *}$ & sample through 1987Q4 \\
\hline GSADF Statistic & $6.1240^{* * *}$ & $\begin{array}{l}\text { sample from 2011Q1 to } \\
\text { 2017Q1 }\end{array}$ \\
\hline \multicolumn{3}{|c|}{ Washington, D. C. } \\
\hline SADF Statistic & $4.2951^{\star * *}$ & sample through 2005Q2 \\
\hline GSADF Statistic & $11.6426^{\star * *}$ & $\begin{array}{l}\text { sample from 1995Q1 to } \\
\text { 2005Q1 }\end{array}$ \\
\hline \multicolumn{3}{|c|}{ Miami } \\
\hline SADF Statistic & $6.4519^{* * *}$ & sample through 2005Q3 \\
\hline GSADF Statistic & $17.8809^{\star * *}$ & $\begin{array}{l}\text { sample from 1987Q2 to } \\
\text { 2005Q3 }\end{array}$ \\
\hline \multicolumn{3}{|c|}{ Atlanta } \\
\hline SADF Statistic & $2.9733^{* * *}$ & sample through 2011Q4 \\
\hline GSADF Statistic & $9.5618^{\star * *}$ & $\begin{array}{l}\text { sample from 2000Q2 to } \\
\text { 2009Q2 }\end{array}$ \\
\hline \multicolumn{3}{|c|}{ Boston } \\
\hline SADF Statistic & $4.3810^{* \star \star}$ & sample through 1985Q4 \\
\hline GSADF Statistic & $12.7284^{* * *}$ & $\begin{array}{l}\text { sample from 1992Q3 to } \\
\text { 2000Q1 }\end{array}$ \\
\hline
\end{tabular}

Notes: The symbols ${ }^{* *}$ and ${ }^{* * *}$ respectively denote significance at $5 \%$ and $1 \%$ level, which are according to the asymptotic one-sided p-values of Phillips et al. (2015). 
Figure 3 is the statistic of the overall housing market in the United States. Three episodes of exuberance were found in the overall housing market: 1998Q2-2007Q3, 2009Q3-2011Q4, and 2016Q4-2018Q1 (the latest piece of data collected). Of these periods, the most significant and longest episode of exuberance was between 2009Q3 and 2011Q4. According to the results, after the financial crises in 2007 and 2008, the housing market recovered quickly and even experienced overheating. It may be that during the financial crises, monetary easing policies had been employed, house prices reflected the influence quickly. Still, rents might not respond promptly due to shortterm rigidity, resulting in higher house prices measured by rents and then the existence of exuberance.

By comparing the estimated results of Table 3 and Figure 3 , it is evident that the overall housing market had started to overheat in 1984Q1 and reached significant exuberance in 1998Q2; the housing market correction started in 2005Q3 until 2007Q3, when the housing exuberance disappeared.

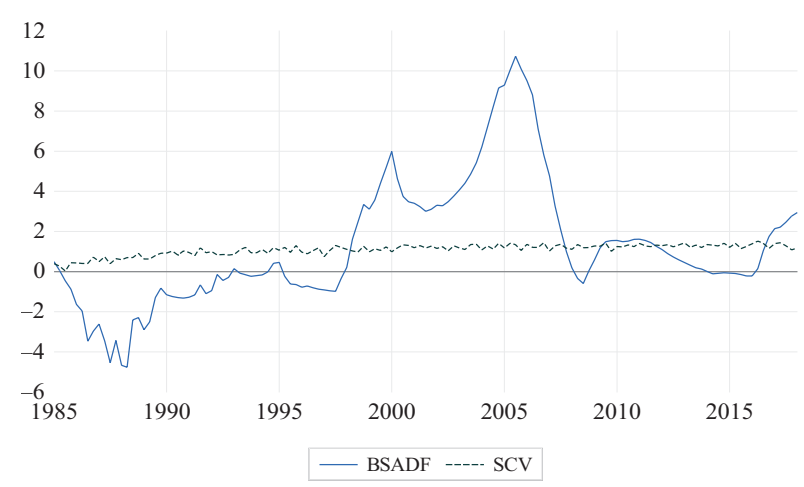

Figure 3. The statistics of the BSADF (the overall housing market)
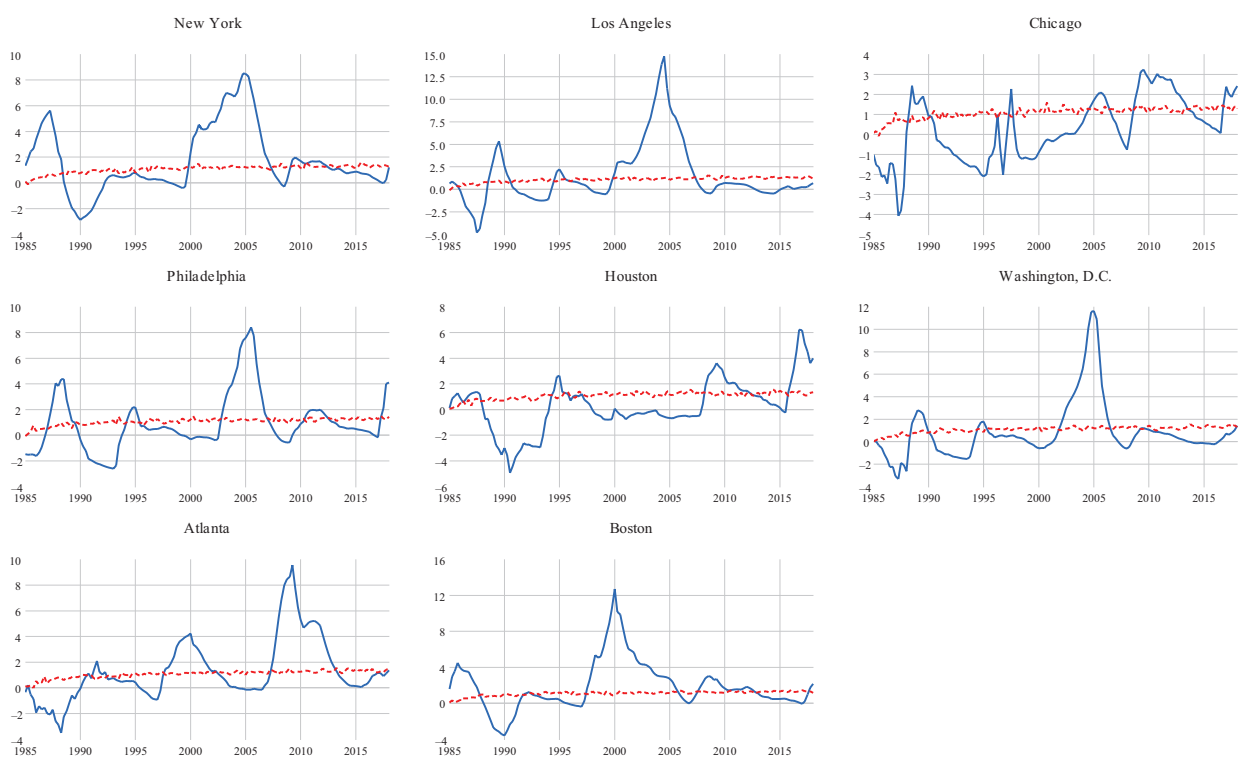

Figure 4 presents the statistics of the 10 MSAs. Although the MSAs have different housing exuberance at different times, episodes of exuberance almost all include 2005. The different time periods and durations of housing exuberance in the MSAs may have been caused by the speed of response to information, correction efficiency, and ripple effects.

The estimated results shown in Table 3, Figure 3, and Figure 4 are consistent with previous research (e.g. Engsted et al., 2016; Pavlidis et al., 2016; Tsai \& Chiang, 2019), which signifies that price-rent ratios diverge in certain periods, indicating a significant period when the house prices deviate from the rental costs. As described in Equation (6), research has typically excluded the effects of mortgage interest rates. Therefore, if the ratio of $P_{t} / R_{t}$ does not converge towards a constant, it signifies a house price bubble. The following predicts the relative bubble size of house prices to rental costs (house price deviation).

Table 4 shows the equilibrium relationship between house prices and rental costs determined using the fully modified least squares (FMOLS) method in an attempt to evaluate the deviation of house prices from rental costs. The reason why this study employs FMOLS is that the variables involved are nonstationary, and predicting relationships between these variables directly may lead to the spurious regression problem. An increasing number of researchers have made efforts to develop methods to evaluate the relationships between nearly integrated regressors, and FMOLS estimation is one the common methods that enables researchers to use nonstationary data to explore the information implied by long-term relationships. Therefore, the present study employs the FMOLS estimation to obtain unbiased long-term relationships between house prices and rental costs, thereby obtaining the deviation value of house prices from rental costs.

$$
\text { — BSADF ---- SCV }
$$

Figure 4. The statistics of the BSADF (MSAs) 
Table 4. Results of FMOLS estimation

\begin{tabular}{|c|c|c|c|c|}
\hline Region & \multicolumn{4}{|c|}{$P_{i}$} \\
\hline United States & Coefficient & Std. Error & $t$-Statistic & $p$-value \\
\hline$R_{i}$ & $141.6882^{\star * *}$ & 8.3661 & 16.9360 & 0.0000 \\
\hline Constant & -5665.8086 & 7855.9670 & -0.7212 & 0.4719 \\
\hline \multicolumn{5}{|l|}{ New York } \\
\hline$R_{i}$ & $182.1770^{* * *}$ & 15.3133 & 11.8966 & 0.0000 \\
\hline Constant & 2109.6290 & 21440.8500 & 0.0984 & 0.9217 \\
\hline \multicolumn{5}{|l|}{ Los Angeles } \\
\hline$R_{i}$ & $257.5904^{\star * *}$ & 19.0796 & 13.5008 & 0.0000 \\
\hline Constant & $-103754.5395^{\star * *}$ & 30745.8707 & -3.3746 & 0.0009 \\
\hline \multicolumn{5}{|l|}{ Chicago } \\
\hline$R_{i}$ & $127.2233^{* * *}$ & 11.4960 & 11.0668 & 0.0000 \\
\hline Constant & 8030.4841 & 12856.9029 & 0.6246 & 0.5332 \\
\hline \multicolumn{5}{|l|}{ Dallas } \\
\hline$R_{i}$ & $65.0969^{* * *}$ & 5.0570 & 12.8727 & 0.0000 \\
\hline Constant & $71678.4966^{* * *}$ & 4871.0751 & 14.7151 & 0.0000 \\
\hline \multicolumn{5}{|l|}{ Philadelphia } \\
\hline$R_{i}$ & $138.8947^{* * *}$ & 7.6485 & 18.1598 & 0.0000 \\
\hline Constant & 1699.8927 & 7799.6770 & 0.2179 & 0.8278 \\
\hline \multicolumn{5}{|l|}{ Houston } \\
\hline$R_{i}$ & $70.6541^{\star * *}$ & 4.8737 & 14.4971 & 0.0000 \\
\hline Constant & $55216.4471^{\star * *}$ & 4846.3177 & 11.3935 & 0.0000 \\
\hline \multicolumn{5}{|l|}{ Washington, D. C. } \\
\hline$R_{i}$ & $172.3818^{\star \star \star}$ & 11.7435 & 14.6790 & 0.0000 \\
\hline Constant & 15096.1459 & 15036.1345 & 1.0040 & 0.3170 \\
\hline \multicolumn{5}{|l|}{ Miami } \\
\hline$R_{i}$ & $119.8555^{\star * *}$ & 15.0631 & 7.9569 & 0.0000 \\
\hline Constant & 172.9803 & 17056.7955 & 0.0101 & 0.9919 \\
\hline \multicolumn{5}{|l|}{ Atlanta } \\
\hline$R_{i}$ & $110.6055^{\star \star \star}$ & 9.0512 & 12.2200 & 0.0000 \\
\hline Constant & $24439.4305^{\star * *}$ & 7901.0396 & 3.0932 & 0.0024 \\
\hline \multicolumn{5}{|l|}{ Boston } \\
\hline$R_{i}$ & $194.7129^{\star * *}$ & 12.9132 & 15.0786 & 0.0000 \\
\hline Constant & -18295.9434 & 17477.8468 & -1.0468 & 0.2968 \\
\hline
\end{tabular}

Notes: $P_{i}$ represents the house prices in the region $i . R_{i}$ represents the rental costs in the region $i$. The symbol *** denotes significance at $1 \%$ level.

Although Table 3, Figure 3, and Figure 4 depict the periods of short-term deviation of house prices from rental costs, these estimation results fail to explain if house prices have an integrated relationship with the rental costs in the long term. Table 5 details the unit root test results estimated using house price deviation with consideration of the structural changes. The results show that significant integration of house prices and rental costs are found in only Los Angeles and Miami after considering structural changes. Moreover, as shown in Tables 3 and 5, the house prices in the overall U.S. market and the majority of the MSAs were inefficient; the house prices did not correct towards the rental costs. Without considering the effects of the mortgage interest rate, the empirical results indicate that the housing market participants are irrational; specifically, these participants continue to buy houses even when the costs of buying are higher than those of renting, thereby increasing the house price deviation from rental costs, increasing house price bubbles.

Figure 5 depicts the time series chart of mortgage interest rates. ${ }^{2}$ Based on the estimation results presented in Table 3, the period in shadow is the most likely period of housing exuberance in the U.S. housing markets (i.e., between 1984Q1 and 2005Q3). As shown in Figure 5 , the mortgage interest rates dropped comparatively

2 The datum used in this study is the average 30-year mortgage interest rate in the United States. 
Table 5. Unit root test results estimated using house price deviation

\begin{tabular}{|c|c|c|}
\hline MSA & $t$-Statistic & $p$-value \\
\hline \multicolumn{3}{|c|}{ United States } \\
\hline Break date & 2014Q3 & \\
\hline Augmented Dickey-Fuller test & -3.9282 & 0.1819 \\
\hline \multicolumn{3}{|c|}{ New York } \\
\hline Break date & 1998Q3 & \\
\hline Augmented Dickey-Fuller test & -3.6764 & 0.2939 \\
\hline \multicolumn{3}{|c|}{ Los Angeles } \\
\hline Break date & 2009Q3 & \\
\hline Augmented Dickey-Fuller test & $-4.4455^{\star *}$ & 0.0498 \\
\hline \multicolumn{3}{|c|}{ Chicago } \\
\hline Break date & 2007Q1 & \\
\hline Augmented Dickey-Fuller test & -2.8799 & 0.7482 \\
\hline \multicolumn{3}{|c|}{ Dallas } \\
\hline Break date & 2016Q1 & \\
\hline Augmented Dickey-Fuller test & -1.9299 & 0.9858 \\
\hline \multicolumn{3}{|c|}{ Philadelphia } \\
\hline Break date & 1986Q1 & \\
\hline Augmented Dickey-Fuller test & -4.1350 & 0.1160 \\
\hline \multicolumn{3}{|c|}{ Houston } \\
\hline Break date & 2016Q1 & \\
\hline Augmented Dickey-Fuller test & -2.7362 & 0.8162 \\
\hline \multicolumn{3}{|c|}{ Washington, D. C. } \\
\hline Break date & 2007Q1 & \\
\hline Augmented Dickey-Fuller test & -4.1731 & 0.1054 \\
\hline \multicolumn{3}{|c|}{ Miami } \\
\hline Break date & 2004Q4 & \\
\hline Augmented Dickey-Fuller test & $-5.3910^{\star * *}$ & 0.0100 \\
\hline \multicolumn{3}{|c|}{ Atlanta } \\
\hline Break date & 2017Q3 & \\
\hline Augmented Dickey-Fuller test & -2.9708 & 0.7025 \\
\hline \multicolumn{3}{|c|}{ Boston } \\
\hline Break date & 2007Q1 & \\
\hline Augmented Dickey-Fuller test & -3.0381 & 0.6638 \\
\hline
\end{tabular}

Notes: The selection of break date is based on the minimum Dickey-Fuller $t$-statistic. The critical values of $t$-statistic are $-4.9491,-4.4436$, and -4.1936 at the $1 \%, 5 \%$, and $10 \%$ level, respectively. The symbols ${ }^{* *}$ and ${ }_{* * *}$ denote significance at $5 \%$ and $1 \%$ level, respectively.

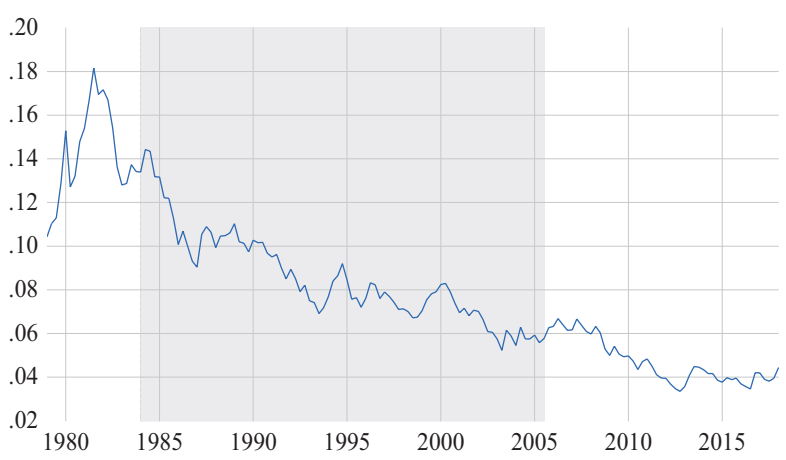

Figure 5. The time series chart of mortgage interest rates significantly in the same period. Decreases in the interest rates would slow down the rate of increase of user costs that accompanies the rise of house prices. Thus, inferring housing market participants to be irrational with the results in Table 3 alone might lead to underestimation of the efficiency of the housing markets.

Accordingly, this study uses the equilibrium condition of the housing and rental markets in Equation (7) to assess whether $\left(P_{t} \times r_{t}^{r m}\right) / R_{t}$ is a stationary sequence. In other words, it uses the ratio of user costs $\left(P_{t} \times r_{t}^{r m}\right)$ to rental costs to identify episodes of housing exuberance and present the results in Table 6. As can be seen, neither the overall U.S. market nor the 10 MSAs exhibited an episode of significant exuberance. The results are consistent with the findings of Shi (2017), which used the unit-root test

Table 6. Results of SADF and GSADF tests (the ratio of user costs to rental costs)

\begin{tabular}{|c|c|c|}
\hline MSA & Statistic & Period \\
\hline \multicolumn{3}{|c|}{ United States } \\
\hline SADF Statistic & -0.5695 & sample through 1993Q3 \\
\hline GSADF Statistic & 0.5364 & sample from 2004Q3 to 2010Q3 \\
\hline \multicolumn{3}{|c|}{ New York } \\
\hline SADF Statistic & -0.6911 & sample through 2012Q4 \\
\hline GSADF Statistic & 0.5891 & sample from 2004Q3 to 2010Q3 \\
\hline \multicolumn{3}{|c|}{ Los Angeles } \\
\hline SADF Statistic & -0.6504 & sample through 1987Q1 \\
\hline GSADF Statistic & 1.2956 & sample from 1993Q2 to 2006Q2 \\
\hline \multicolumn{3}{|c|}{ Chicago } \\
\hline SADF Statistic & -0.6312 & sample through $2012 \mathrm{Q} 4$ \\
\hline GSADF Statistic & 0.7148 & sample from 2004Q3 to 2010Q3 \\
\hline \multicolumn{3}{|c|}{ Dallas } \\
\hline SADF Statistic & -0.2735 & sample through 1993Q3 \\
\hline GSADF Statistic & 0.8400 & sample from 1997Q1 to 2003Q2 \\
\hline \multicolumn{3}{|c|}{ Philadelphia } \\
\hline SADF Statistic & -0.6105 & sample through $2012 \mathrm{Q} 4$ \\
\hline GSADF Statistic & 0.5622 & sample from 2004Q4 to 2012Q3 \\
\hline \multicolumn{3}{|c|}{ Houston } \\
\hline SADF Statistic & -0.2492 & sample through 1987Q1 \\
\hline GSADF Statistic & 0.5173 & sample from 1997Q1 to 2003Q2 \\
\hline \multicolumn{3}{|c|}{ Washington, D. C. } \\
\hline SADF Statistic & -0.6110 & sample through 2012Q4 \\
\hline GSADF Statistic & 0.6685 & sample from 2004Q3 to 2010Q3 \\
\hline \multicolumn{3}{|c|}{ Miami } \\
\hline SADF Statistic & -0.3961 & sample through 1993Q3 \\
\hline GSADF Statistic & 1.5870 & sample from 1996Q3 to 2006Q2 \\
\hline \multicolumn{3}{|c|}{ Atlanta } \\
\hline SADF Statistic & -0.4504 & sample through 1993Q3 \\
\hline GSADF Statistic & 0.6271 & sample from 2004Q4 to 2011Q3 \\
\hline \multicolumn{3}{|c|}{ Boston } \\
\hline SADF Statistic & -0.4504 & sample through 1993Q3 \\
\hline GSADF Statistic & 0.6271 & sample from 2004Q4 to 2011Q3 \\
\hline
\end{tabular}


method proposed by Phillips et al. (2015) to estimate both the price-rent ratio and non-fundamental components. It is found that the results of the non-fundamental component sequence, compared with that of the actual price-rent ratio, show that the number of regions where the housing market bubble occurs is less and the bubble period is shorter.

Figures 6 and 7 present the dynamic BSADF test statistics. The BSADF test results are nonsignificant (not exceeding SCV) for the overall market during the sample period (Figure 6); thus, user costs and rental costs remain integrated and the evidence of excessively high user costs is nonsignificant. The statistics of the housing markets of the 10 MSAs are shown in Figure 7 and imply that short episodes of housing exuberance emerged in Los Angeles and Miami in 2006Q2. This period was before the $2007 \mathrm{fi}-$ nancial crisis. If the housing bubble is caused by irrational expectations, before the housing bubble bursts, investors may have the highest expectations for house prices, so

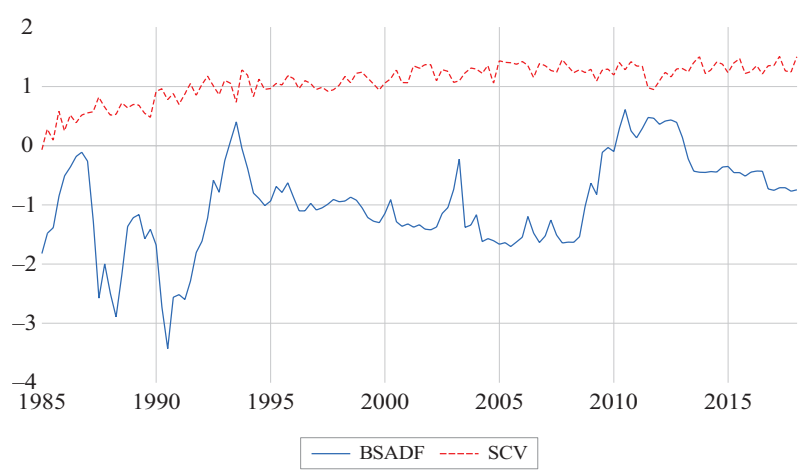

Figure 6. BSADF test using user costs and rental costs (the overall housing market) there will be extreme bids that lead to transactions with the highest house prices. Therefore, the housing markets were overheating before the 2007 financial crisis, but were followed by immediate corrections. As shown in Table 5, after considering structural changes, significant evidence of the integration of house prices and rental costs was found in Los Angeles and Miami. The results of Figure 7 verify the results in Table 5, namely the existence of an equilibrium relationship between housing and rental markets, which can immediately correct short-term deviations. However, as shown in Table 5, the integration of house prices and rental costs was not found in other MSAs, meaning that the user costs of those MSAs were not prominently high during the sample period.

\section{Conclusions}

This study compiles statistical data of house prices and rental costs in the overall housing market and 10 major MSAs in the United States from 1979Q1 to 2018Q1 to evaluate housing exuberance. Due to the rigidity of rents documented by previous studies, using the price-rent ratio to diagnose housing exuberance may result in biased estimations. From the theoretical framework, this paper explains that conducting tests considering the effects of mortgage interest rates on user costs can more properly estimate housing exuberance episodes. This study infers that equilibrium relationships between housing and rental markets will bring mortgage costs (i.e., multiplying house prices by one term of mortgage interest rates) in a given term equal to rental costs in the same term when market participants engage in rational behavior with respect to housing tenure choice.
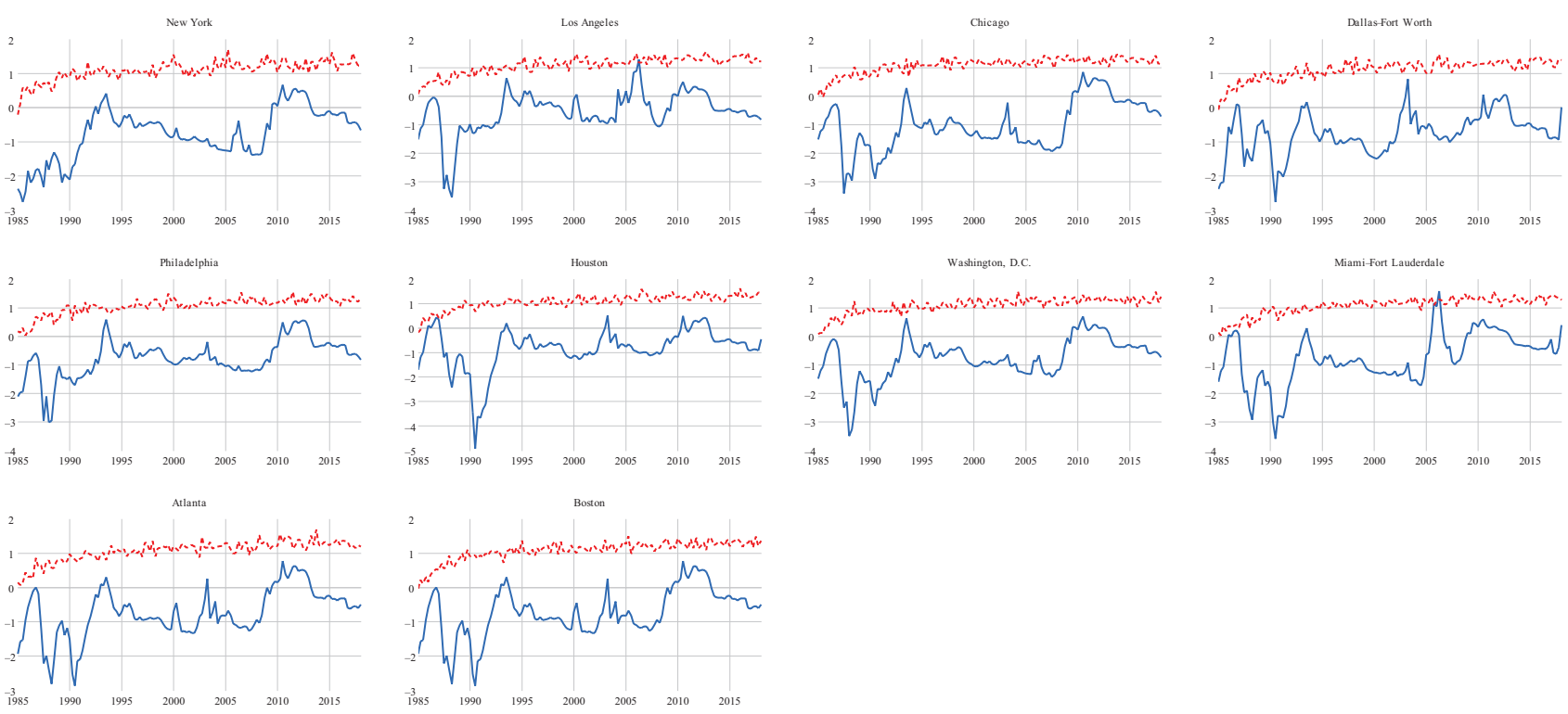

— BSADF ---- SCV

Figure 7. BSADF test using user costs and rental costs (MSAs) 
From the perspective of housing tenure choice, this study used the user-cost-rent ratio that incorporates mortgage interest rates to determine if housing markets are overheated relative to rental markets to further identify episodes of exuberance in housing markets. The test method provided in this article could be more economically meaningful than the direct test of the price-rent ratio.

The empirical results estimated using the price-rent ratio indicate that the episode of overall housing exuberance in the United States was most likely from 1984Q1 to 2005Q3. Housing exuberance also emerged significantly in all MSAs. However, considering the effects of the mortgage interest rates, this study uses the ratio of user costs to rental costs to conduct tests. The results indicate that the evidence of housing exuberance is nonsignificant in either the United States or the 10 MSAs. The study further uses the dynamic housing exuberance indicator to identify short-term episodes of housing exuberance that emerged in two MSAs, Los Angeles and Miami, in 2006Q2, which were followed by immediate corrections. Thus, after considering structural changes, the estimation results yield significant evidence of integration of house prices and rental costs in Los Angeles and Miami. However, the user costs of other MSAs were not excessively high during the sample period, and no significant evidence of house price corrections was found.

The results of this study explain that participants in the U.S. housing markets engaged in rational behavior with respect to housing tenure choice, thereby maintaining the equilibrium relationship between the housing and rental markets. To maintain the price-rent ratio as a stationary sequence, it is necessary to control mortgage interest rates. Specifically, when the reciprocal of mortgage interest rates is not divergent, the price-rent ratio converges towards a constant. This study highlights the importance of interestrate policy for maintaining housing market equilibrium. If the central bank of a country decides to lower interest rates to stimulate housing markets, it is necessary to monitor its effects on the price-rent ratio. In particular, starting from 2020, in order to prevent the decline in economic prosperity caused by the Covid-19 pandemic, the Federal Reserve implemented a fairly loose monetary policy, causing US interest rates have fallen to close to zero. Whether such a low interest rate will disrupt the balanced relationship between rents and house prices is a subject worthy of observation in future research.

\section{Acknowledgements}

We are immensely grateful to Professor Audrius Banaitis (Editor in Chief) and the three anonymous referees for the constructive comments of this paper.

\section{References}

Alkay, E. (2015). Housing choice structure: examples of two different-size cities from Turkey. International Journal of Strategic Property Management, 19(2), 123-136.

https://doi.org/10.3846/1648715X.2015.1029563
André, C., Gupta, R., \& Muteba Mwamba, J. W. (2019). Are housing price cycles asymmetric? Evidence from the US states and metropolitan areas. International Journal of Strategic Property Management, 23(1), 1-22.

https://doi.org/10.3846/ijspm.2019.6361

Been, V., Ellen, I. G., \& House, S. (2019). Laboratories of regulation: understanding the diversity of rent regulation laws. Fordham Urban Law Journal, 46(5), 1041-1079.

https://ir.lawnet.fordham.edu/ulj/vol46/iss5/1

Bourassa, S. C., \& Yin, M. (2008). Tax deductions, tax credits and the homeownership rate of young urban adults in the United States. Urban Studies, 45(5-6), 1141-1161.

https://doi.org/10.1177/0042098008089981

Bourassa, S. C., Hoesli, M. E., \& Oikarinen, E. (2019). Measuring house price bubbles. Real Estate Economics, 47(2), 534-563. https://doi.org/10.1111/1540-6229.12154

Bourassa, S. C., Hoesli, M. E., \& Scognamiglio, D. (2010). Housing finance, prices, and tenure in Switzerland. Journal of Real Estate Literature, 18(2), 261-282.

https://doi.org/10.1080/10835547.2010.12090281

Brunnermeier, M. K., \& Julliard, C. (2008). Money illusion and housing frenzies. Review of Financial Studies, 21(1), 135-180. https://doi.org/10.1093/rfs/hhm043

Campbell, J. Y., \& Shiller, R. J. (1988). Stock prices, earnings, and expected dividends. Journal of Finance, 43(3), 661-676. https://doi.org/10.2307/2328190

Campbell, J. Y., \& Shiller, R. J. (1998). Valuation ratios and the long-run stock market outlook. Journal of Portfolio Management, 24(2), 11-26. https://doi.org/10.3905/jpm.24.2.11

Campbell, S. D., Davis, M. A., Gallin, J., \& Martin, R. F. (2009). What moves housing markets: a variance decomposition of the rent-price ratio. Journal of Urban Economics, 66(2), 90102. https://doi.org/10.1016/j.jue.2009.06.002

Chen, A. (1996). China's urban housing reform: price-rent ratio and market equilibrium. Urban Studies, 33(7), 1077-1092. https://doi.org/10.1080/00420989650011519

Chu, F.-N., \& Tsai, I-C. (2020). Do higher house prices indicate higher safety? Price volatility risk in major cities in Taiwan. International Journal of Strategic Property Management, 24(3), 165-181. https://doi.org/10.3846/ijspm.2020.12159

Engsted, T., \& Pedersen, T. Q. (2015). Predicting returns and rent growth in the housing market using the rent-price ratio: evidence from the OECD countries. Journal of International Money and Finance, 53, 257-275.

https://doi.org/10.1016/j.jimonfin.2015.02.001

Engsted, T., Hviid, S. J., \& Pedersen, T. Q. (2016). Explosive bubbles in house prices? Evidence from the OECD countries. Journal of International Financial Markets, Institutions and Money, 40, 14-25. https://doi.org/10.1016/j.intfin.2015.07.006

Feng, Q., \& Wu, G. L. (2015). Bubble or riddle? An asset-pricing approach evaluation on China's housing market. Economic Modelling, 46, 376-383.

https://doi.org/10.1016/j.econmod.2015.02.004

Fonseca, M. B. F., Ferreira, F. A., Fang, W., \& Jalali, M. S. (2018). Classification and selection of tenants in residential real estate: a constructivist approach. International Journal of Strategic Property Management, 22(1), 1-11. https://doi.org/10.3846/ijspm.2018.317

Genesove, D. (2003). The nominal rigidity of apartment rents. Review of Economics and Statistics, 85(4), 844-853. https://doi.org/10.1162/003465303772815763

Hamilton, J. D. (1986). On testing for self-fulfilling speculative price bubbles. International Economic Review, 27(3), 545-552. https://doi.org/10.2307/2526680 
Hill, R. J., \& Syed, I. A. (2016). Hedonic price-rent ratios, user cost, and departures from equilibrium in the housing market. Regional Science and Urban Economics, 56, 60-72. https://doi.org/10.1016/j.regsciurbeco.2015.11.001

Himmelberg, C., Mayer, C., \& Sinai, T. (2005). Assessing high house prices: bubbles, fundamentals and misperceptions. Journal of Economic Perspectives, 19(4), 67-92. https://doi.org/10.1257/089533005775196769

Hoffmann, J., \& Kurz-Kim, J.-R. (2006). Consumer price adjustment under the microscope: Germany in a period of low inflation (Bundesbank Series 1 Discussion Paper No. 2006, 16). https://ssrn.com/abstract=2785242

Kent, R. J. (1984). Housing tenure choice: evidence from time series. Journal of Urban Economics, 15(2), 195-209. https://doi.org/10.1016/0094-1190(84)90014-7

Kishor, N. K., \& Morley, J. (2015). What factors drive the pricerent ratio for the housing market? A modified present-value analysis. Journal of Economic Dynamics and Control, 58, 235249. https://doi.org/10.1016/j.jedc.2015.06.006

Leamer, E. E. (2002, June). Bubble trouble? Your home has a P/E ratio too. UCLA Anderson Forecast. http://www.uclaforecast. com/uploads/forecasts/2002/june/articles/bubble.asp

Mikhed, V., \& Zemčík, P. (2009). Testing for bubbles in housing markets: a panel data approach. Journal of Real Estate Finance and Economics, 38(4), 366-386. https://doi.org/10.1007/s11146-007-9090-2

Nowak, K., Gluszak, M., \& Belniak, S. (2020). Dynamics and asymmetric rent adjustments in the office market in Warsaw. International Journal of Strategic Property Management, 24(6), 428-440. https://doi.org/10.3846/ijspm.2020.13647

Pavlidis, E., Yusupova, A., Paya, I., Peel, D., Martínez-García, E., Mack, A., \& Grossman, V. (2016). Episodes of exuberance in housing markets: in search of the smoking gun. Journal of Real Estate Finance and Economics, 53(4), 419-449. https://doi.org/10.1007/s11146-015-9531-2

Phillips, P. C. B., \& Yu, J. (2011). Dating the timeline of financial bubbles during the subprime crisis. Quantitative Economics, 2(3), 455-491. https://doi.org/10.3982/QE82

Phillips, P. C. B., Shi, S., \& Yu, J. (2015). Testing for multiple bubbles: historical episodes of exuberance and collapse in the S\&P 500. International Economic Review, 56(4), 1043-1078. https://doi.org/10.1111/iere.12132

Phillips, P. C. B., Wu, Y., \& Yu, J. (2011). Explosive behavior in the 1990s NASDAQ: when did exuberance escalate asset values. International Economic Review, 52(1), 201-226. https://doi.org/10.1111/j.1468-2354.2010.00625.x
Poterba, J. M. (1984). Tax subsidies to owner-occupied housing: an asset-market approach. Quarterly Journal of Economics, 99(4), 729-752. https://doi.org/10.2307/1883123

Poterba, J. M. (1991). House price dynamics: the role of tax policy and demography. Brookings Papers on Economic Activity, 1991(2), 143-203. https://doi.org/10.2307/2534591

Rapaport, C. (1992). Rent regulation and housing-market dynamics. American Economic Review, 82(2), 446-451. https://www.jstor.org/stable/2117442

Reichert, A. K. (1990). The impact of interest rates, income, and employment upon regional housing prices. Journal of Real Estate Finance and Economics, 3(4), 373-391. https://doi.org/10.1007/BF00178859

Shi, S. (2007). Moving window unit root test: locating real estate price bubbles in Seoul apartment market [Master thesis]. Singapore Management University, Singapore. http://ink.library.smu.edu.sg/etd_coll/28/

Shi, S. (2017). Speculative bubbles or market fundamentals? An investigation of US regional housing markets. Economic Modelling, 66, 101-111. https://doi.org/10.1016/j.econmod.2017.06.002

Shimizu, C., Nishimura, K. G., \& Watanabe, T. (2010). Residential rents and price rigidity: micro structure and macro consequences. Journal of the Japanese and International Economies, 24(2), 282-299. https://doi.org/10.1016/j.jjie.2009.12.006

Tabner, I. T. (2016). Buying versus renting - determinants of the net present value of home ownership for individual households. International Review of Financial Analysis, 48, 233-246. https://doi.org/10.1016/j.irfa.2016.10.004

Tsai, I-C. (2020). Price rigidity and vacancy rates: the framing effect on rental housing markets. Journal of Real Estate Finance and Economics (in press).

https://doi.org/10.1007/s11146-020-09791-4

Tsai, I-C., \& Chiang, S.-H. (2019). Exuberance and spillovers in housing markets: evidence from first- and second-tier cities. Regional Science and Urban Economics, 77, 75-86. https://doi.org/10.1016/j.regsciurbeco.2019.02.005

Xie, Y., \& Liu, H. (2004). Price-rent ratio in China's housing market: proper interval, measurement and an empirical study. International Journal of Strategic Property Management, 8(2), 73-86. https://doi.org/10.3846/1648715X.2004.9637509

Zorn, P. M. (1988). An analysis of household mobility and tenure choice: an empirical study of Korea. Journal of Urban Economics, 24(2), 113-128. https://doi.org/10.1016/0094-1190(88)90034-4 